\title{
The Effect of Flow Mind Map on Writing Accuracy and Learning Motivation at Islamic Higher Education
}

\author{
Sabarun \\ IAIN Palangka Raya \\ sabarunwhs@gmail.com \\ Aisyah H.S. El-Muslimah \\ UNNES \\ saffura@student.unnes.ac.id \\ Slamet Muhanif \\ IAIN Palangka raya \\ slametmuhanif@gmail.com \\ Tazkiyatunnafs Elhawwa \\ Universitas Muhammadiyah Palangkaraya \\ tazkiyatunnafs.elhawwa@umpr.ac.id
}

\begin{abstract}
the investigation attempted to explore the influence of flow mind map on writing accuracy and learning motivation at Islamic Higher Education. There were two variables: flow mind map as a predictor variable; writing accuracy and learning motivation as the outcome variables. The study involved L2 participants at higher education in Kalimantan. The participants was 37 students, consisting of two groups: experiment class and control class. A main effect of one way Anova was used to measure an effect of flow mind map on learners' writing score and learning motivation. The finding revealed that the value of writing accuracy at $\mathrm{F}(1,36)=44.861$, SS 3591.045, MS $=3591.045, \mathrm{p}=0.000$; and the value of learning motivation at $\mathrm{F}(1,36)=40.925$, SS 2006.600, $\mathrm{MS}=2006.600, \mathrm{p}=0.000$. The significance value was below 0.050 , meaning there was a statistically difference in the mean of using flow mind map on learners' writing accuracy and learning motivation. It was recommended that language instructor motivate learners during the learning process. Due to the limited number of sample size, the further investigations with broader scope and larger sample size were needed to validate the research findings.
\end{abstract}

Keywords: flow mind map, writing accuracy, learning motivation.

\section{INTRODUCTION}

Writing is a complex skill understood well by language learners. The skill covers grammatical devices, writing mechanics, sentence structures, and rhetorical devices. L2 Writing is more complex than L1 writing. It needs creative thinking and critical thinking. Learners should understand the relevant knowledge related to the topic chosen, select word choices, use transition signals appropriately, develop paragraphs into a good essay and so on. This demands a creative thinking to do. In facts, learners still face a number of problems I writing. Anwar (2000) mentions some problems such as lack knowledge of the topic, less practice, and not adequate feedback from teachers. Besides, teachers tend to focus on grammar dan sentence structures (Calhoun, \& Hale, 2003). Additionally, Forsyt (2003) confirmed that the learners' poor writing skills due to the poor motivation and attitudes on writing class. Learners frequently see themselves as insufficient student writers. This view is also supported by Kear (2000) stating that from grade to grade, learners' perception on writing get worse and low 
motivation. Therefore, the students cannot find writing as an interesting activity. They are never interested to write (Artell, 2005). Consequently, learners often face difficulties in writing, such as insecurity, unwillingness, lack of vocabulary, and so on (Bing Duan Yuan, 2011, p. 235-236, Rico, 2013, p.65, Elhawwa, 2019, Sabarun, 2020). As a result, the learners' motivation is low. Therefore, language instructors should invite learners to involve in and construct the learning process (Wells, 1999). In writing class, language instructors need to introduce the writing process to learners, design classroom setting providing learners to communicate with teachers and peers. Learners' participation will not occur unless the learner is motivated intrinsically. Therefore, enabling learners to improve writing skills and learning motivation, flow mind map is proposed to implement in writing class during the semester.

Mind map is based on radiant thinking. Mind map activates more functions of brain to organize learning, especially in writing class. It tells how human brain processes information (AlJarf, 2011; Buzzle, 2012; Murley, 2007. Mind map is a procedure to create notes as brief and interesting as possible. The principle of mind map is that moving ideas from abstract to concrete (Meier, 2007). Mind map is used as a writing assisteant to brainstorm ideas. In mind map, subsequent ideas are connected, structuring a hierarchical map. It is a teaching technique helping language instructors to introduce many words connected with a single topic. Therefore, mind map is a procedure to create notes as brief and interesting as possible. It is used as a writing assistant to brainstorm ideas.
Mind map evidenced to be an easy way to create notes in several ways (Brinkmann, 2003), Mind map is a tool to record, note and train brain (Buzan, 2005). It indicates how each idea is connected (Khoo, 2006). Mind map provides learners more active in the process of learning (Edwards and Cooper, 2010), and it is suitable for university learners (Murley, 2007), and it allows quick writing (Edwards and Cooper, 2010). In writing context, it is an appropriate instrument to brainstorm a topic of an essay. It begins with writing down a key idea and connecting ideas radiated out from the centre. By doing so, learners map information such a way helping them understand and retain information. It is also used to develop ideas with association. It can be used to generate ideas, visualize, organize, plan and revise the topic. Additionally, mind map provides a tool to brainstorm a topic. Flow maps are to display a process of something. They are used to indicate the object movement amongst different areas. They are also used to display animal migrations, people traveling, money flow, trade traffics, etc. The arrows indicate direction, while the width illustrates the quantity. Flow map is necessary since it shows the quantity contrast of huge item variety on a vast territory. It provides consumers trend, spread patterns, disaster movements etc. In writing, it can be used to plan an essay writing, classifying objects, exemplification essay, and illustration essay. In this case, using lines on a flow map is the same as using symbols on other types of mind maps (Chang, 2012). The model of flow map is illustrated in Figure 1. 


\section{Structure of a Persuasive Essay}

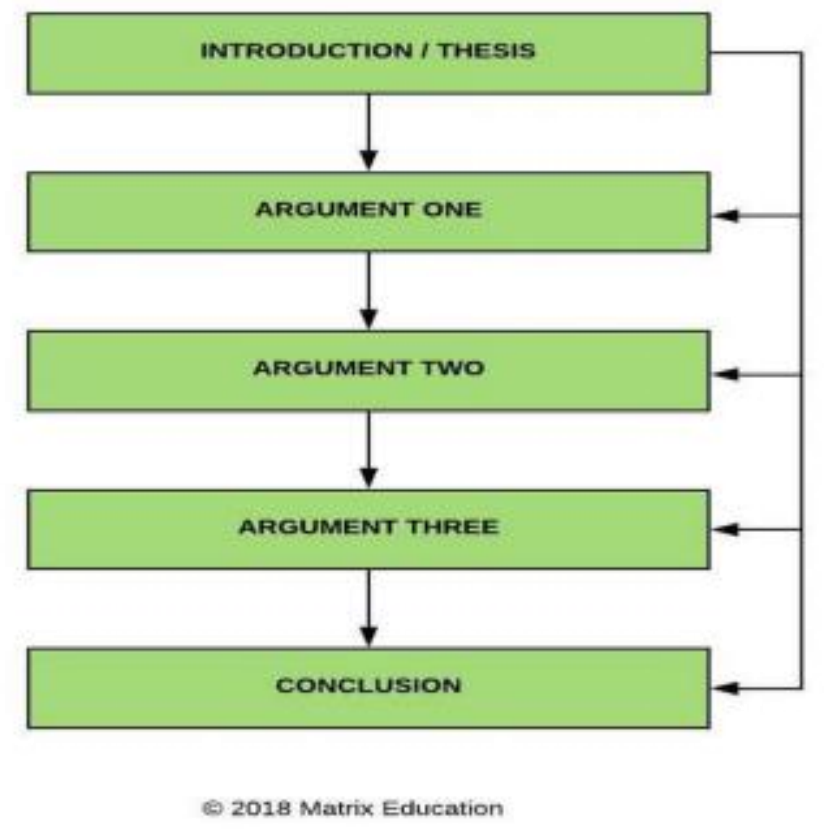

Figure 1. The model of flow map

Another model of flow mind map is multi- express causes of an event and state effect. For flow map. A multi flow map is applied to indicate correlation amongst events. It is suitable to plan instance, learners want to write cause and effect of cause and effect essays, since it enables learners to earthquake recently. They can create a mind map as shown in Figure 2.

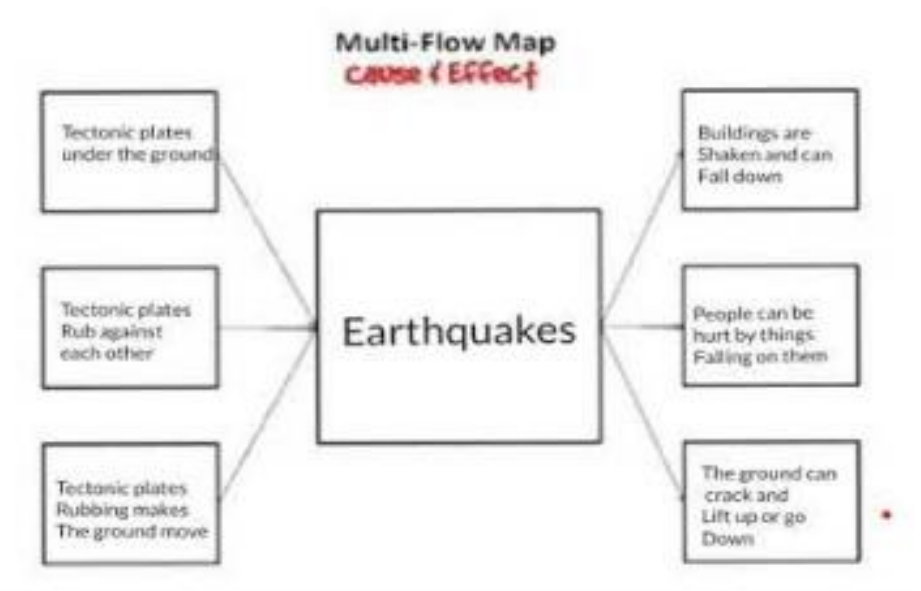

Figure 2.The model of multi-flow map

As mentoned before, there are many benefits of using flow mind map in process writing. Writing process needs high creativity. Lim, Yunus and Mohamed Amin (2017) state that writing process is important for communication. Then, Yunus and Chan (2016) focused on the benefits of mind map in structuring ideas, understanding topic and generating ideas. Meanwhile, Mercer
(2002) states that mind map helps learners in connecting ideas aids and in linking information. Here, mind map is helpful before, during and after writing. It helps learners to plan and to organize their writing products (Keles, 2012; Bharambe, 2012). The other benefits of mind map is for maximizing right brain (Buzan, 2005, p. 7). Meanwhile, Willis and Willis (2007, p. 79), confirm 
that mind map provides learners to focus on relevant information, and to organize information coherently. In addition, mind map software is more attractive and professional (Dara, 2010). It is easier to produce and effective in inhanching language learning. Peng (2011) found that mind map could improve generating ideas by connecting the role of left and right brain, since it covers language processing. Mind Map also increases creativity and mental visualization (Benavides, Rivera \& Rubio, 2010; Hofland, 2007). The following are the steps of writing an expository essay with a mind map as illustrated in Table 1.

Table 1. The steps to write expository essay using mind map

\begin{tabular}{|c|c|}
\hline Steps & Activities \\
\hline Introduction & $\begin{array}{l}\text { An Expository essay is written to expose or explain some kind of truth or fact about a } \\
\text { particular topic. The writers need to know that the purpose here is to inform the } \\
\text { readers. The essay prioritizes factual information and its description over personal } \\
\text { bias or opinions. This is a step-by-step guide to assist them in crafting an impressive } \\
\text { expository essay. }\end{array}$ \\
\hline hoose a topic & $\begin{array}{l}\text { The writers should remember that an expository essay is written to provide } \\
\text { information to the readers. So it is obvious that they should not choose a generic topic } \\
\text { that readers are already well-informed on. They have to find a topic that is lesser- } \\
\text { known in general but is familiar to the writers. This will make it easy for them to } \\
\text { conduct research. It is not easy to arrive at such a topic. This is where mind-mapping } \\
\text { will help them out. }\end{array}$ \\
\hline $\begin{array}{l}\text { Use mind- } \\
\text { mapping to select } \\
\text { a topic }\end{array}$ & $\begin{array}{l}\text { A mind-map visually articulates the writers' thought-process and stimulates their } \\
\text { imagination to inspire new ideas and perceptions. They can easily make a mind-map } \\
\text { with software to draw one. Mind mapping techniques can help writers select a topic. }\end{array}$ \\
\hline $\begin{array}{l}\text { Do extensive } \\
\text { research }\end{array}$ & $\begin{array}{l}\text { Quality research is the backbone of an expository essay. Here, facts do all the writing. } \\
\text { So it is crucial to perform thorough research. Use information from only reputed } \\
\text { sources. Take extreme care to refer to studies, research papers, academic journals and } \\
\text { publications that are reliable and trustworthy. Search for government data and figures } \\
\text { related to the topic. Make sure the author the writers are referencing is credible and } \\
\text { qualified. Take notice of the number of citations that the author has provided to } \\
\text { support his/her work. It will give them an idea about how reliable the research is. } \\
\text { Also, make sure the authors and publications the writers relying upon are objective } \\
\text { and up to date. They can manage it with flow min map. }\end{array}$ \\
\hline $\begin{array}{l}\text { Integrate the } \\
\text { research using } \\
\text { mind-maps }\end{array}$ & $\begin{array}{l}\text { Mind-maps simplify the complex process of research by consolidating information } \\
\text { into a cohesive structure. The writers may construct separate mind maps for different } \\
\text { sources or make a common mind-map that documents all the sources. Create distinct } \\
\text { branches/bubbles for different pages, paragraphs, and quotations, that they have } \\
\text { incorporated in their essay. It will help them to eliminate unnecessary information and } \\
\text { avoid repetition }\end{array}$ \\
\hline & $\begin{array}{l}\text { There are five kinds of structures that guide writers on how to write an expository } \\
\text { essay. they should finalize one among these five or combine two or more to attain a } \\
\text { suitable framework depending upon the topic: (a) Illustration. (b) Classification. } \\
\text { Under this type of essay, a broad subject matter is covered by breaking it down into } \\
\text { several sub-categories. The approach is to start from the generic category and proceed }\end{array}$ \\
\hline
\end{tabular}


by classifying sub-groups. (c) Compare/contrast. These essays are comparative studies to highlight similarities and differences between two units of objects. (d) Cause-effect. The essays falling under this structure establishes causality of a particular topic and discusses its effect to suggest solutions based on those implications. (e) Process. These are procedural essays that elaborate on the process of accomplishing a particular task or goal. In the present study, the learners are directed to apply flow maps.

Create an outline An expository essay is usually written following the basic structure of Introductionof the essay using Body-Conclusion. The introduction comprises the thesis statement, three paragraphs mind-mapping form the body and another paragraph concludes the essay. Design the outline according to this structure and attach a deadline to avoid delay. Utilize mind-mapping software to extract the final outline as a word document as use it as a template for the essay.

Make a mind map 1. Begin with the main concept.

2. Add branches to the main concept. For example

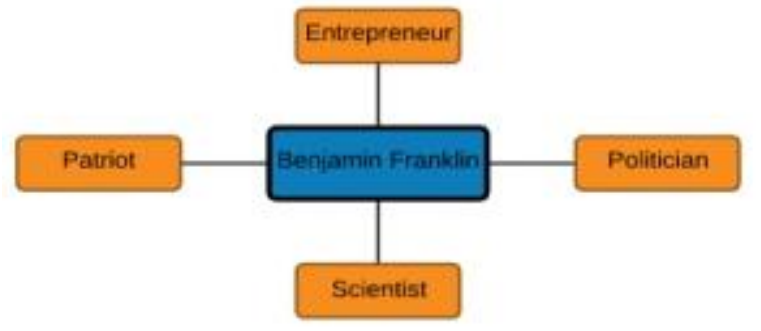

3. Explore topics by adding more branches.

4. Add images and colors.

Craft a thesis The thesis statement in an expository essay is quite different from the one that is statement written for argumentative essays. Here, the statement does not need writers' opinion on the topic, rather it just makes the reader know what the essay is about. The thesis just introduces the reader to the topic and provides a glimpse into what will follow.

Start drafting the The writers now have everything they need. They have topic, thesis, research, and essay outline ready and so they should proceed to write the first draft of the essay.

Proof-reading and Once the writers have finished writing, do a thorough revision of essay by editing proofreading it. It will give them an idea of whether they have covered the subject matter in a logical sequence or not. They must check that the introduction and thesis statement are coherent for the reader. Make sure the writing has remained focused throughout the essay and the conclusion is concise and effective. Eliminate parts that are incoherent or unnecessary.

Conclusion It is an interesting endeavor to learn how to write an expository essay. writers will come out at the other end of this process with more knowledge and understanding about an issue. Teaching someone else is the best way to obtain command over a particular subject or topic.

The steps of teaching writing using flow mind map was adopted from Borkar (2011) and Harkirat et.al (2011, p. 190), namely: First the language instructor introduces a mind map application and all components in its toolbar to the learners. Learners should be able to practice using the software. Second, the language instructor gives a model of expository texts and create a note of the major topic in the screen. Third, the language instructor demonstrates to apply the software and starts drawing branches on all sides of the major idea. Fourth, the language instructor and the 
learners demonstrate to draw arrows to map out the idea. Fifth, the language instructor assigns learners to form a group consisting 4 or 5 members for each. Sixth, the language instructor asks each learner to make a mind map on the plan of the essay. Seventh, the language instructor asks each learner to write an essay referring to the mind map they have create. Eighth, the language instructor asks each learner to submit their final product of writing. Ninth, the language instructor together with the learners makes a discussion about the mind map and composition they have made. The model of mind map for writing expository essay is illustrated in Figure 3.

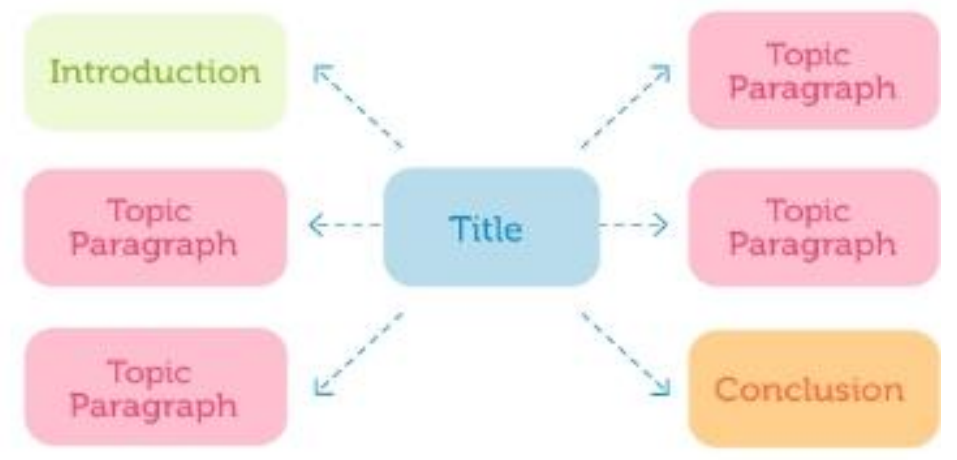

Figure 3. The model of mind map for writing expository essay

In L2 writing context, motivation is an attempt in which combining learners' attitudes, desires to write in the target language (Richard et al, 2002, p. 343). It has two meanings: the learners' movement to write, and the readers' movement to read the writing product. Motivation can be divided into two kinds: intrinsic and extrinsic motivation (Harmer, 2007). Intrinsic motivation is the learners' own desires to write. It came from the inside learners' motive to do something. In contrast, extrinsic motivation is the learners' interest and desires to write because of external benefits, such as grade, reward, gift and so on. In L2 writing, learners with intrinsic motivation write using the target language because of their own interest. Therefore, they liked to spend all of their time to write. In L2 learning context, motivation is categorized into two kinds: integrative and instrumental motivation (Brown, 2007). The first refers to a purpose to integrate language, culture, and community. Meanwhile, the second types of motivation refers a tool to achieve the goal. There are several aspects shaping learners' motivation to write, for example, attitudes, beliefs, desires and willingness, and attitude. Learners who cannot complete those aspects of motivation are known as reluctant writers or unsuccessful writers. Sometimes, they got difficulties in writing. There are some models of unsuccessful writers, such as having poor spelling and punctuation skills; working slowly and frequently not finishing tasks, poor presentation, delaying writing, lacking of life experience, and refusing to share their composition with peer. In contrast, there are also some models of successful writers having high motivation, such as they do not avoid the writing tasks, always keep on writing task, follow the additional course required for writing, submitting the writing task on time, showing higher intrinsic motivation to write, putting more efforts to enhance writing tasks.

Many experts investigated some studies on the impact of mind map strategy on students' writing (Al-Jarf, 2009; Al-Naqbi, 2008; and motivation (Cain, 2001/2002; Goodnough \& Woods, 2002; Jones, et al, 2012; Keles, 2012; and Polson, 2004). Some researchers recently attempted to explore the implementation of mind map strategy 
in various fields. Although, mind map is evidenced to be helpful to increase writing ability, there is still a lack of mind investigation in Kalimantan, especially in higher education. Only few researchers found the impact of mind map strategy on students' writing motivation. Furthermore, the discussion of the integration between mind map strategy and software in writing is relatively new. In other words, there were still limited number of studies investigating the impact of mind map on learners' learning motivation and writing accuracy as their main focus. Therefore, this study attempts to bridge the gap. The finding of the study is expected to give practical solution for teaching writing. It is hoped to give some benefits to stakeholders, curriculum designers, both teacher and learners. Therefore, the research questions of the study: (a) does flow mind map give effect on writing accuracy? (b) Does flow mind map give effect on learning motivation?

\section{METHODOLOGY}

The study used a quasi-experiment design. The investigation was performed during the whole semester in three stages: pre experiment, experiment, post experiment stages. Pre experiment stage took place for one week. It covered giving pretest and distributing learning motivation questionnaire to both experiment and control class. Experiment stages covered giving the materials of expository essay writing, and giving intervention. In control class, the materials were given as well as in experiment class. However, the intervention differed. In this class, the participants were directed to use free writing technique in their pre writing strategy. Before starting to write, learners wrote the first draft freely. Then, they edited the draft in the next steps. In contrast, in experiment class, the materials were given as well as in control class. The intervention was directed to use flow mind map technique in their pre writing strategy. Here, the mind map technique was, first, socialized to the class involving installing the application software of mind map and the procedures to perform mind map software. Before starting to write, learners create a writing plan in a mind map. Afterwards, they wrote the text based on mind map they created. This stage took place for 13 weeks. In post experiment stage, both classes were given posttest and assigned to fill learning motivation questionnaire. This was done to get the data of participants' writing ability and their learning motivation after intervention. It took place for a week.

Table 2. Stages in data collection

\begin{tabular}{lll}
\hline \multicolumn{1}{c}{ stages } & \multicolumn{1}{c}{ Control group (Non-mind map class) } & Experiment group (mind map class) \\
\hline $\begin{array}{l}\text { Pre-experiment } \\
\text { (week 1) }\end{array}$ & Writing achievement pretest & Writing achievement pretest \\
\cline { 2 - 3 } $\begin{array}{l}\text { Experiment (week } \\
\text { two until fourteen) }\end{array}$ & $\begin{array}{l}\text { Teaching writing essay materials cover: } \\
\text { introduction to essay writing, structure of } \\
\text { essay, element of essay, transitional } \\
\text { signals, developing paragraphs into essay }\end{array}$ & $\begin{array}{l}\text { Teaching writing essay materials } \\
\text { cover: introduction to essay writing, } \\
\text { structure of essay, element of essay, } \\
\text { transitional signals, developing } \\
\text { paragraphs into essay }\end{array}$ \\
\hline Giving treatment & $\begin{array}{l}\text { In prewriting steps, the class used free } \\
\text { writing. }\end{array}$ & $\begin{array}{l}\text { In prewriting steps, the class used } \\
\text { mind map. }\end{array}$ \\
\cline { 2 - 4 } & $\begin{array}{l}\text { Introducing free writing technique in } \\
\text { prewriting strategy }\end{array}$ & socializing E-mind map to learners \\
\cline { 2 - 4 } & Practicing writing using free writing. & practicing writing using mind map \\
\cline { 2 - 4 } & Free writing sessions & E-mind map sessions in writing \\
\hline $\begin{array}{l}\text { Post experiment } \\
\text { (week fifteen) }\end{array}$ & $\begin{array}{l}\text { Writing achievement posttest } \\
\text { Students were assigned to compose an }\end{array}$ & $\begin{array}{l}\text { Writing achievement posttest } \\
\text { Students were assigned to compose }\end{array}$ \\
\hline
\end{tabular}


expository text about four or five paragraphs in 450-500 words. an expository text about four or five paragraphs in 450-500 words.
The chart explained the procedures of collecting data. At the first meeting, the non-mind map class as the control as well as the mind map class (the experiment group) received pretest and fulfilled the motivation questionnaire. This was performed to know the learners' writing ability and the level of learning motivation. Then during meeting two until fourteen, both classes were given different treatment. Both classes were given the same materials of expository essay writing. The control class was taught using free writing strategy in writing instructions. During the learning process in the whole semester, each class were taught the same materials such as introduction to expository essay writing, the structure of an essay, and the development of an essay. During the writing class, they implemented three steps in writing process. However, they obtained different treatment. The experiment group was treated using flow mind map. Meanwhile, the control class was not given any treatment (non-mind map). They were given freewriting strategy. Step 1 was planning. In planning step, they were given the materials of expository essay. Individually, they selected the interesting topic. Step 2 was drafting. In drafting, they wrote the first draft. Here, before writing the first draft, each class was given different treatment as mentioned above. Step 3 was editing and publishing. In this step, they revised the composition on sentence structure, punctuation, diction, grammar rules, organization, and so on. Afterward, they wrote the final product and submitted to the teacher. At the end of semester, all class were given posttest and questionnaire motivation. They were assigned to write an expository essay about 450-500 words. Each learner was assigned about four to five paragraphs of an expository essay in 90 minutes. The score was based on content, organization, sentence structure, and mechanics. The learners' writing product was scored using the scoring method as proposed by Weigle (2002, p. 116). The scores of each class were compared to see the effect of flow mind map on writing accuracy and learning motivation in writing class. Finally, the data were gathered and tabulated using SPSS program (Pallant, 2007). The null hypotheses were: (a) Flow mind map does not give effect on writing accuracy; (b) flow mind map does not give effect on learning motivation.

\section{Participants}

The study recruited 37 university learners consisting of experiment group $(n=19)$ and control group $(n=18)$. They were the learners who joined writing class at that semester. There were two variables: flow mind map technique as the predictor variable; writing accuracy and learning motivation were the outcome variables. Therefore, the theoretical thinking of the research was described in Figure 4.

\section{Flow Mind Map}

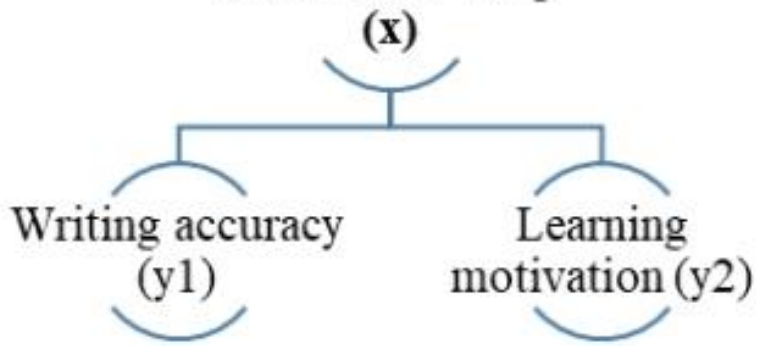

Figure 4. Theoretical framework 
An analysis of variance was applied to calculate the effect of flow mind map on writing accuracy and learning motivation at Islamic Higher Education. Here, it determined if there was an effect of flow mind map on writing accuracy and learning motivation. This study was performed at higher education in Kalimantan. The number of the subjects was 37 L2 learners, as explained in Table 3.

Table 3. The participants of the study

\begin{tabular}{llll}
\hline \multirow{2}{*}{ Groups } & \multicolumn{2}{c}{ Outcome variable (y) } & total \\
\cline { 2 - 3 } & $\begin{array}{l}\text { Writing } \\
\text { accuracy }(\mathrm{y} 1)\end{array}$ & Learning motivation (y2) & \\
\hline $\begin{array}{l}\text { Experiment class (using flow } \\
\text { mind map) }\end{array}$ & 19 \\
\hline Control class (using freewriting) & \multicolumn{2}{c}{37} \\
\hline Total
\end{tabular}

\section{Validity and Reliability}

To meet the validity of the test, face validity and content validity were used. Then, reliability was done using correlation product moment calculation by applying it to a pilot study of (10) students (outside from the sample). The result of $r$ value was (0.88), which was in accordance with this study.

\section{Data Analysis}

Responding to the two research questions; a one way ANOVA main effect was conducted. It was used to calculate the main effect of flow mind map (x) on the learners' writing accuracy (y1) and learning motivation (y2). All of the data were calculated using SPSS program.

\section{RESULT AND DISCUSSION}

The assumption test was performed before testing the hypothesis.

\section{Assumption test}

The test assumption performed was normality test and homogeneity test, as illustrated in Table 4.

Table 4. Tests of Normality

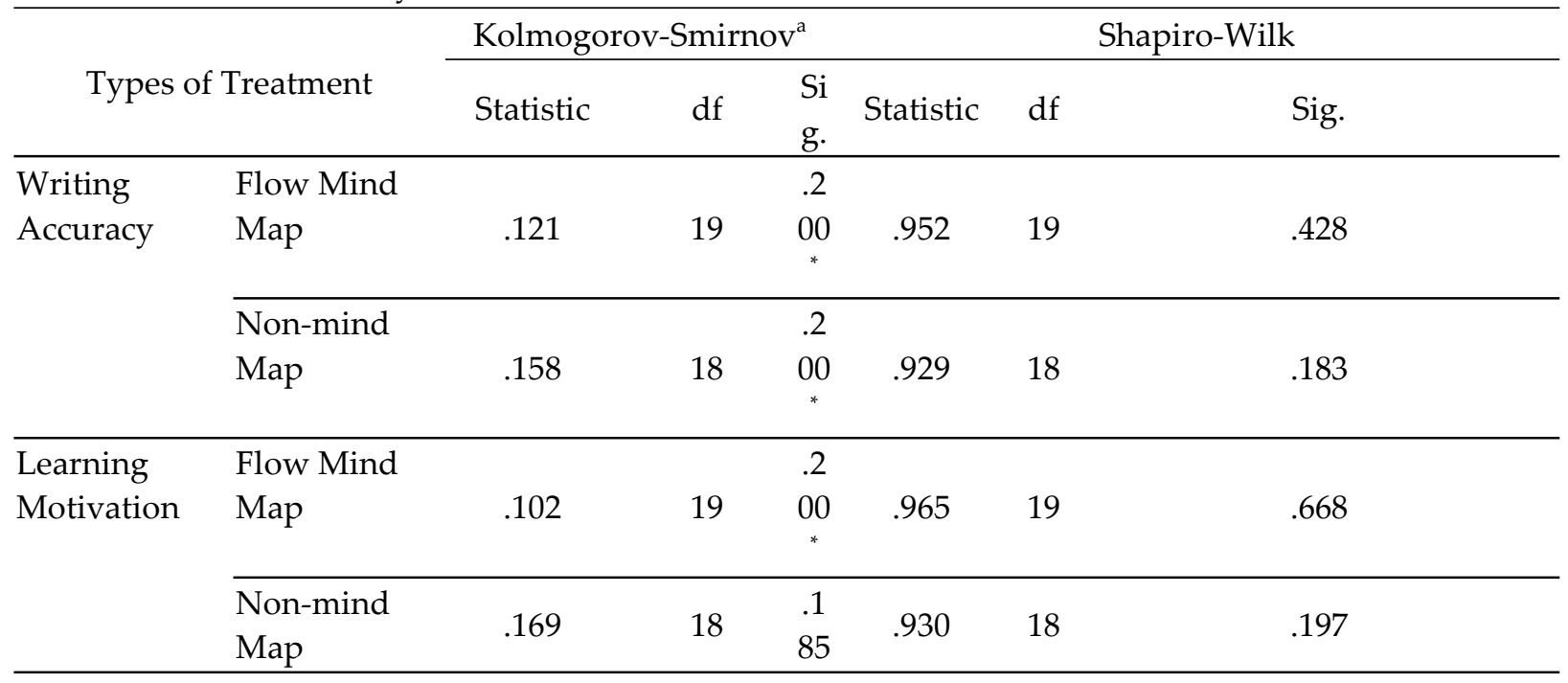


The output confirmed that the sig value of Shapiro-Wilk on writing accuracy using flow mind map was 0.428 ; without using flow mind map 0.183; learning motivation using flow mind map was 0.668 ; without using flow mind map 0.197.
Since they were higher than 0.050 , it was said that the data was normally distributed. The QQ Plot was also used to see the normality of data as shown in Figure 5.
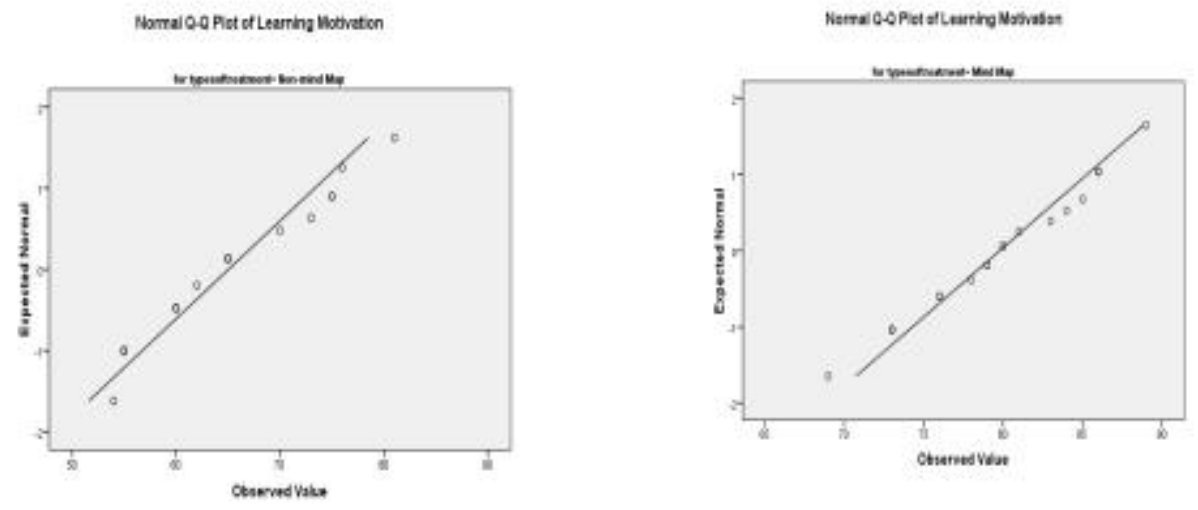

Figure 5. The QQ plot of learning motivation

The next step wasto find the homogeneity. Table 5 showed the homogeneity test, as follows:

Table 5. Levene's Test of Equality of Error Variances

\begin{tabular}{lllll}
\hline & Levene Statistic & df1 & df2 & Sig. \\
\hline Writing Accuracy & 2.382 & 1 & 35 & .132 \\
\hline Learning Motivation & 2.832 & 1 & 35 & .101 \\
\hline
\end{tabular}

The output Levene's Test confirmed that $\mathrm{F}$ value of writing accuracy was $2.382, \mathrm{p}=0.132 ; \mathrm{F}$ value of learning motivation was $2.382, p=0.101$. Since they were higher than 0.050 , it was said that the data were not violated the homogeneity.

\section{Testing hypothesis}

There were two research questions of this study. RQ1: Does flow mind map give effect on writing accuracy? RQ 2: Does flow mind map give effect on learning motivation? There are two variables: flow mind map technique as the predictor variable; writing accuracy and learning motivation were the outcome variables. To test the seven hypotheses, there were some procedures to be performed. First, the mean score for each variable was described in Table 6.

Table 6. The mean score of each variable

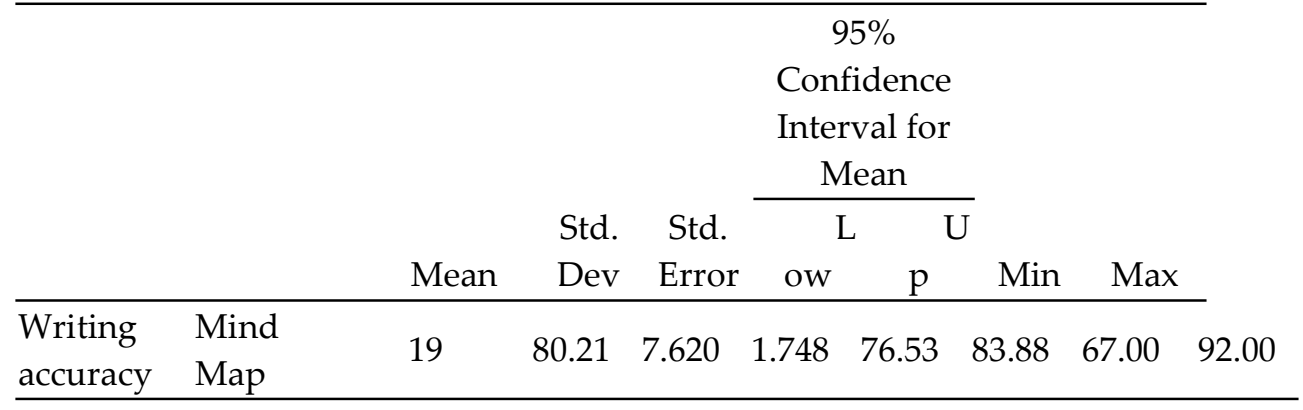




\begin{tabular}{|c|c|c|c|c|c|c|c|c|c|}
\hline & $\begin{array}{l}\text { Non- } \\
\text { mind } \\
\text { Map }\end{array}$ & 18 & 60.50 & 10.16 & 2.395 & 55.44 & 65.55 & 45.00 & 75.00 \\
\hline & Total & 37 & 70.62 & 13.32 & 2.190 & 66.17 & 75.06 & 45.00 & 92.00 \\
\hline \multirow[t]{3}{*}{$\begin{array}{l}\text { Learning } \\
\text { motivation }\end{array}$} & $\begin{array}{l}\text { Mind } \\
\text { Map }\end{array}$ & 19 & 79.78 & 5.503 & 1.262 & 77.13 & 82.44 & 69.00 & 89.00 \\
\hline & $\begin{array}{l}\text { Non- } \\
\text { mind } \\
\text { Map }\end{array}$ & 18 & 65.05 & 8.299 & 1.956 & 60.92 & 69.18 & 54.00 & 81.00 \\
\hline & Total & 37 & 72.62 & 10.16 & 1.671 & 69.23 & 76.01 & 54.00 & 89.00 \\
\hline
\end{tabular}

The output confirmed that the mean score of learners' writing accuracy using mind map was 80.21 (SD 7.62, SE 1.75, n=19). Meanwhile, the mean score of learners' writing accuracy without using mind map was 60.50 (SD 10.16, SE 2.40, $\mathrm{n}=18$ ). The total means for writing accuracy was $70.62(\mathrm{n}=37)$. In contrast, the mean score of learners' learning motivation using mind map was 79.79 (SD 5.50, SE 1.26, n=19). Meanwhile, the mean score of learners' learning motivation without using mind map was 65.06 (SD 8.30, SE
1.96, $\mathrm{n}=18$ ). The total means for writing accuracy was $72.62(n=37)$. Based on the output, it was concluded that learners using flow mind map performed better on writing accuracy and learning motivation than those who did not use flow mind map.

Flow mind map did not give effect on writing accuracy and learning motivation

To respond the first and second research question, the main effect of one way ANNOVA was performed, as shown in Table 7.

Table 7. ANOVA main effect

\begin{tabular}{|c|c|c|c|c|c|c|}
\hline & & $\begin{array}{l}\text { Sum of } \\
\text { Squares }\end{array}$ & $d f$ & Mean Square & $F$ & Sig. \\
\hline \multirow[t]{3}{*}{$\begin{array}{l}\text { Writing } \\
\text { Accuracy }\end{array}$} & $\begin{array}{l}\text { Between } \\
\text { Groups }\end{array}$ & 3591.04 & 1 & 3591.045 & 44.861 & .000 \\
\hline & $\begin{array}{l}\text { Within } \\
\text { Groups }\end{array}$ & 2801.65 & 35 & 80.047 & & \\
\hline & Total & 6392.70 & 36 & & & \\
\hline \multicolumn{2}{|c|}{ Learning Between } & 2006.60 & 1 & 2006.600 & 40.925 & .000 \\
\hline \multirow[t]{3}{*}{ Motivation } & Groups & & & & & \\
\hline & $\begin{array}{l}\text { Within } \\
\text { Groups }\end{array}$ & 1716.10 & 35 & 49.031 & & \\
\hline & Total & 3722.703 & 36 & & & \\
\hline
\end{tabular}

The output revealed that the value of writing accuracy at $\mathrm{F}(1,36)=44.861$, SS 3591.045, MS=3591.045, $p=0.000$. The significance value was below 0.050 , and therefore, it was said that a statistically difference occurred in the average score of using flow mind map on learners' writing accuracy. The mean plot below described the mean score of each group.

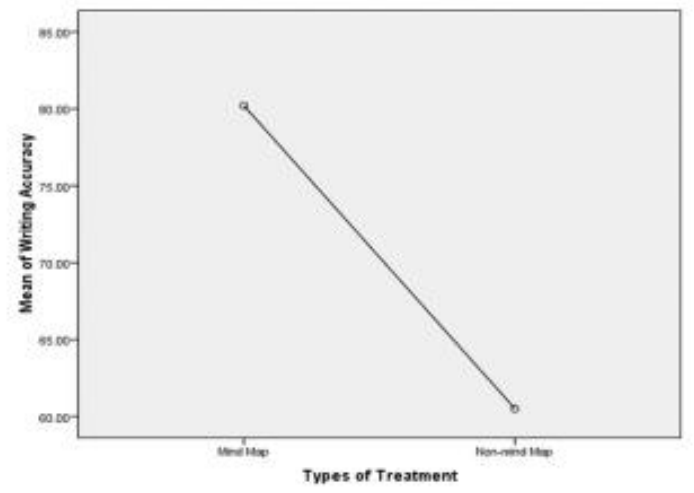


Figure 6. The mean plot of writing accuracy.

The figure described that the mean plot for writing accuracy using flow mind map performed better achievement than those without flow mind map.

The output of the second row also revealed that the value of learning motivation at $F(1,36)=40.925$, SS 2006.600, MS= 2006.600, $\mathrm{p}=0.000$. The significance value was below 0.050, and therefore, it was said that a statistically difference occurred in the average score of using flow mind map on learners' learning motivation. It was concluded that there was a statistically significant difference in the mean of using flow mind map on writing accuracy and learners' learning motivation. It was also

seen in the mean plot for learning motivation as shown in Figure 7.

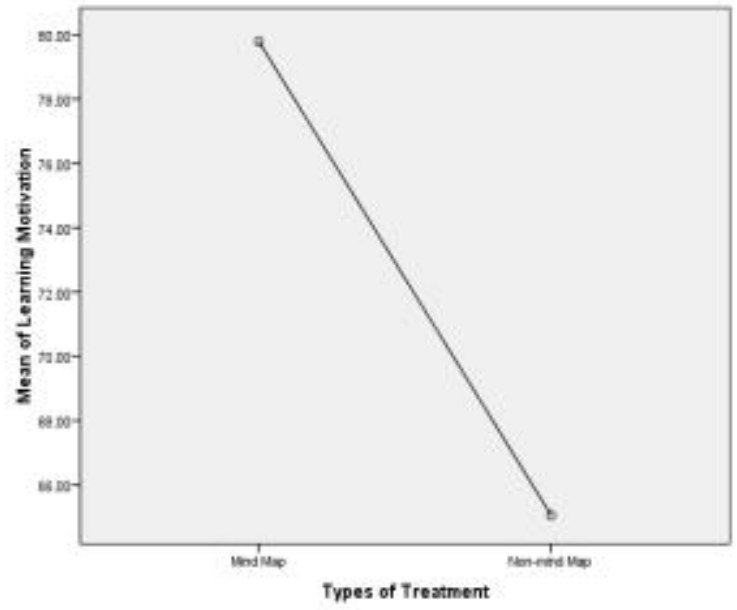

Figure 7. The mean plot of writing accuracy.

The figure described that the mean plot for learning motivation using flow mind map performed better achievement than those without flow mind map.

\section{CONCLUSION}

In general, the output of ANOVA table revealed that the value of writing accuracy at $\mathrm{F}$ $(1,36)=44.861$, SS 3591.045, MS= 3591.045, $\mathrm{p}=0.000$; and the value of learning motivation at $\mathrm{F}(1,36)=$ 40.925, SS 2006.600, MS= 2006.600, $\mathrm{p}=0.000$. The significance value was below 0.050 , and therefore, a statistically difference occurred in the mean of using flow mind map on learners' writing accuracy and learning motivation.

\section{DISCUSSION}

The finding revealed that there was a statistically significant difference in the mean of using flow mind map on learners' writing accuracy and learning motivation. This finding was supported by some other researchers in various field of study such as (Al-Jarf, 2009; AlNaqbi, 2008; Cain, 2001/2002; Goodnough \& Woods, 2002; Jones et al, 2012; Farrand, Hussain, and Hennessey, 2002; Harkirat, et al, 2010, Toi, 2009; Zampetakis et al, 2007 Goodnough and Woods, 2002; D'Antoni and Zipp, 2005; Holland et al, 2003/2004; Mueller et al, 2002;; Ralston and Cook, 2007). This finding was also relevant with previous investigations conducted by Keles (2012); Vijayavalsalan, (2016) found that mind map facilitates learners to enhance writing skills such as organizing ideas, structuring and connecting ideas. Then, Hallen and Sangeetha (2015) found that mind map can increase learners' understanding level in writing class. Morever, Davies (2011) revealed that mind map contributed positive attitude in writing class. Many other investigators confirm that mind map is helpful for writing class. Hdii (2015) concluded that mind map gave facilitative effect on learners' writing achievement. 
Shakoori et al. (2017) mind map can facilitate writing, and make the practice of writing is interesting for learners. In addition, Shakoori \& Kadivar (2015) revealed that using mind map can provide depth learning and improve learners' motivation. Similarly, Tayib (2015) indicated that mind map can improve writing ability and learners had positive attitude toward writing. In addition, the findings were in accordance with previous investigations evidencing the helpful of mind map instruction for writing class (Nurlaila, 2013; Padang \& Gurning, 2014).

Dealing with the finding on mind map and motivation, the experiment group achieved better than the control group. The experimental class indicated bigger motivation than control group in writing. This was probably due to some factors. The first factor might come from inside factors from learners. Some learners in experiment group were actively joining extra campus organization such debate club, conversation club, and student research club. This probably affected their learning experience and their capability to communicate ideas. By demonstrating them the way to write an essay using flow mind map, they could connect easily their experiences to their writing form. In this case, Rico (2013, p.58) confirmed some aspects contributing to learning atmosphere such as personality, motivation, experiences, and cognition. The second factor might probably come from learners' learning atmosphere such as curriculum design, culture, and motivation. Additionally, the experimental class taught using flow mind map could work well in conducive atmosphere. Therefore, the learners' learning motivation improved better. The potential factor contributing to learners' significant increase in writing accuracy and learning motivation was that facilitation of constructivism theory of learning. The constructivist believes that learners can best learn through experience in learning process. It was also confirmed by Fiktorius (2013), explaining that mind map provides learners to plan, create, and construct new ideas. Referring to the aforementioned points, it can be concluded that the experimental class performed better on writing accuracy and writing motivation than control class.
The treatment using flow mind map in this investigation evidenced that mind map gave facilitative effect on learners' writing. Regarding the positive finding in this investigation, therefore, flow mind map should be regarded as an alternative technique to improve learners' writing skills. The results, ideally, should arouse motivation for both teachers and learners in incorporating mind map in writing class. This urged the curriculum developers and education designers to include mind map in the ELT curriculum. It was also recommended that the next researchers to perform similar investigation on the effect of mind map in writing class with different level of learners and bigger sample size for more authentic analysis and findings.

\section{Acknowledgments}

The greatest appreciation is due to all academicians for supporting scientific helps.

\section{Bio Statement:}

Sabarun (M.Pd) holds Master Degree in English Language Education from Universitas Negeri Malang (2006). He has been working as an English lecturer at IAIN Palangka Raya, Indonesia since 2008. He is now positioned as the head of quality assurance board at his university. $\mathrm{He}$ published ten papers and presented in international events such as Inacelt (2019), English Language Teaching journal (2018), Ellic (2019), Ijer (2017, 2020), Vision (2020), Sys Rev Pharm (2020), Elementary Education Online (2020), proceeding ACE 2020. Proceeding SEACE 2021. His focus research is in TESOL, learning writing strategies, and learning styles. No Orcid ID https://orcid.org/0000-00033427-626X. Scopus ID 57216373264. Email: sabarunwhs@gmail.com

Aisyah Hafshah Saffura el-Muslimah (M.Li) is a post graduate student of Universitas Sebelas Maret Surakarta, Indonesia. She is interested in Descriptive Linguistics studies and English Teaching method. She is now a student researcher at Universitas Negeri Semarang. ORCID ID: https://orcid.org/0000-0002-4190-0254 
Slamet Muhanif is a student of English

Department of Institut Agama Islam Negeri

Palangka Raya, Indonesia.

\section{REFERENCES}

Abi-El-Mona, I. \& Adb-El-Khalick, F. (2008). The Influence of Mind Mapping on Eighth Graders' Science Achievement. School Science and Mathematics, 180(-), 298-312.

Al Naqbi, S. (2011). The use of mind mapping to develop writing skills in UAE schools. Education, Business and Society: Contemporary Middle Eastern Issues, 4(2), 120-133.

Al-Jarf, R. (2009). Enhancing Freshman Students' Writing Skills with a Mind Mapping Software. Paper Presented at the 5th International Scientific Conference, $e$ Learning and Software for Education.

Anwar, I. Z. (2000). The effect of using peer review groups in teaching essay writing to fourth year English majors, Faculty of Education, on their writing performance, apprehension, revising and attitudes. Journal of Research in Education and Psychology. 14(1), 94-129.

Artell, T (2005). Quality of Service in Network based Automation. MSc Thesis, in Finnish. Tampere University of technology.

Benavides, S., Rivera, F., \& Rubio, M., (2010). Improving reading comprehension skills by using mind-mapping software with students of bachelor's degree in English attending reading and writing in English II course. (Master thesis) Universidad de Oriente UNIVO.

Bharambe, M. I. (2012). Effectiveness of Mind Mapping in educational psychology. Journal of Biological Chemistry, 2, 10-18.

Bing, D. Y. (2011). How to Motivate Students in Second Language Writing. Sino-US English Teaching. 8 (4), ISSN 1539-8072.

Borkar, R. (2011). How to use mind mapping for studying. $\quad$ http://www.buzzle.com/ articles/mind-mappingforstudying.html.

Brinkmann, A. (2003). Graphical Knowledge Display-Mind Mapping and Concept
Mapping as Efficient Tools in Mathematics Education. Mathematic Education, 16(-).

Brown, H. D. (2007). Teaching by Principle an Interactive Approach to Language Pedagogy. (3rd Ed.). San Fransisco State University.

Buzan, T. (2005). Mind Map Handbook. The Ultimate Thinking Tool. Harper Collins Publishers.

Buzzle.com. (2012). "What is Mind Mapping?"http://www.buzzle.com/ articles/mind-mapping/html.

Cain, M.E. (2001). Using Mind Maps to Raise Standards in Literacy, Improve Confidence and Encourage Positive Attitudes toward Learning'. Newchurch Community Primary School.

Calhoun, S. \& Hale, J. (2003). Improving students writing through different writing styles. M.A. Action Research Project. Saint Xavier University and Skylight Professional Development Field-Based Master's Program.

Chang, C. (2012). Narrative ads and narrative processing. In E. Thorson and S. Rodgers (Eds.), Advertising Theory (pp.241-254). Routledge.

D' Antoni, A.V., \& Pinto Zipp, G. (2005). Applications of the mind map learning technique in chiropractic education. Journal of Chiropractic Education. -(19).

Dara, C. (2010). Hand drawing vs. using software mind mapping. http://www.isoftwarereviews.com/handdrawingvs-using-software-mind-mapping/

Davies, M. (2010). Concept mapping, mind mapping and argument mapping: What are the differences and do they matter? University of Melbourne Press

Davies, M. (2011). Concept mapping, mind mapping and argument mapping: what are the differences and do they matter? Higher education, 62(3), 279-301

Edwards, S. \& Cooper, N. (2010). Mind mapping as a teaching resource. The Clinical Teacher, 7(4), 236-239.

Elhawwa, T, Rukmini, D., Mujiyanto, J. \& Sutopo, D. (2019). The Relationship between Different Sources of Feedback and Learning Motivation 
on Learners' Writing Performance. Test Engineering and Management. 81(-). 4408 - 4420.

Farrand, P., Hussain, F. \& Hennessy, E. (2002). The Efficacy of the Mind Map Study Technique. Medical Education, 36 (5)

Fiktorius, T. (2013). The use of mind-mapping technique in the EFL classroom. https://www.academia.edu/3823093.

Forsyt, D. (2003). Our social world. http://www.alleydog.com \glossary \definitio n.cfm?

Goodnough, K. \& Woods, R. (2002). Student and teacher perceptions of mind mapping: a middle school case study. Paper Presented at the Annual Meeting of American Educational Research Association.

Hallen, D., \& Sangeetha, N. (2015). Effectiveness of mind mapping in teaching English among VIII standard students. Journal on English Language Teaching, 5(1), 45-50.

Harkirat, S, et.al. (2011). Constructivist visual mind map teaching approach and the quality of students' cognitive structure. Journal of Science, Education, and Technology. 20(2).

Harmer, J. (2007). How to Teach Writing. Pearson Education Limited.

Hdii, S. (2015). A comparative study of writing performance by using and without using the technology of mind mapping at the university. ICT for language learning: conference proceedings.

Hofland, C. (2007). Mind-mapping in the EFL classroom. Fontys Teacher Training College Sittard.

Holland, B., Holland, L. \& Davies, J. (2003/2004). An investigation into the concept of Mind Mapping and using Mind Mapping software to support and improve student academic performance. Learning and Teaching Projects. 89-94.

Jones, Brett D, et.al. (2012). The effect of mind mapping activities on students' motivation. International Journal for the Scholarship of Teaching and Learning. 6(1)http://www.georgiasouthern.edu/
Kear, M. (2000). Effects of guided journal writing on students' story understanding. Journal of Educational Research, 95(3). 179-191.

Keles, O. (2012). Elementary teachers' views on mind mapping. International Journal of Education, 4(1), 93-100.

Khoo, A. (2006). I am gifted, so are you. Marshall Cevendish Editions.

Lim, K. I., Yunus, M. M., \& Embi, M. A. (2017). Build me up: overcoming writing problems among pupils in a rural primary school. Jurnal Pendidikan Humaniora, 5(1), 1-7.

Meier, P. (2007). Mind-mapping. Social Research Update, 52, 1-4.

Mercer, N. (2002). Multicultural Education Programs. University of Southern California

Mueller, A., Johnston, M., Bligh, D. \& Wilkinson, J. (2002). Joining mind mapping and care planning to enhance student critical thinking and achieve holistic nursing care. International Journal of Nursing Terminologies and Classifications, 13(1), 24-27

Murley, D. (2007), Technology for everyone: mind mapping complex information. Law Journal Library, 99 (1). 175-183.

Nurliala, A.P. (2013). The use of mind mapping in writing descriptive text. Journal of English and Education, 1(2). 9-15.

Padang, J.S.M., \& Gurning, B. (2014). Improving students' achievement in writing descriptive text through mind mapping strategy. Register Journal of English Language Teaching of FBSUnimed, 3. 1-11.

Pallant, J. (2007). Survival manual: A step by step guide to data analysis using SPSS for Windows. Allen \& Unwin.

Peng, S. (2011). The effect of combining mind map and electronic picture-books on fourthgraders' reading comprehension ability and reading motivation. (Master's thesis). National Pingtung University of Education.

Polson, K. (2003/2004). How Do Pupils and Teachers View using Mind Mapping in Learning \& Teaching? G.T.C Scotland Teacher Researcher Programme. 
Ralston, J. \& Cook, D. (2007). Collaboration, ICT and Mind Mapping. Reflecting Education, 3(1). 61-73.

Richards, J. \& Renandya, W. (2002). Methodology in Language Teaching. Cambridge University Press.

Rico, L.J.A. (2013). Identifying factors causing difficulties to productive skills among foreign language learners. Opening Writing Doors, 10(2). ISSN 23229187. Pamplona, Columbia.

Sabarun, Laela, H.N., Zaitun, Q., Widyastuty, H., El-muslimah, A.H.S, (2020). The relationship among intrinsic/extrinsic motivation and interest toward L2 writing performance at higher education. Elementary Education Online, 19 60-68. http://dx. doi.org/10.17051/ilkonline.2020.02.10 7

Shakoori, M., \& Kadivar, P. (2015). A study on concept mapping as a pre-writing strategy and examining its effect on EFL learners' writing achievement and interest. International Journal of Review in Life Sciences, 5 (3), 1040-1044. http://www.ijiet.org/vol7/894T004.pdf

Shakoori, M., Kadivar, P., \& Sarami, R. (2017). The effect of concept mapping strategy as a graphical tool in writing achievement among EFL learners.

Tayib, A. (2015). The effect of using graphic organizers on writing (A case study of preparatory college students at Umm-AlQura University). International Journal of English Language Teaching, 4 (5), 31-53.

Toi, H. (2009). Research on how Mind Map improves Memory. Paper presented at the International Conference on Thinking, Kuala Lumpur, 22-26 June 2009.

Vijayavalsalan, B. (2016). Mind mapping as a strategy for enhancing essay writing skills. New Educational Review, 45(3). 137-150.

Weigle, S. (2002). Assessing writing. Cambridge University Press.

Wells, G. (1999). Dialogic Inquiry: Towards a Socio-Cultural Practice of Theory and Education. Blackwell.

Willis, C.L. and Miertschin, S.L. (2006). Mind maps as active learning tools. Journal of Computing Sciences in Colleges, 21(4). 266-272.

Willis, D., \& Willis, J. (2007). Doing Task-Based Teaching. Oxford University Press.

Yunus, M. M., \& Chan, H. C. (2016). the use of mind mapping strategy in malaysian university english test (MUET) Writing. Creative Education, 7(January). 619-626. https://doi.org/10.4236/ce.2016.7406

Zampetakis, L.A., Tsironis, L., \& Moustakis, V. (2007). Creativity Development in Engineering Education: The Case of Mind Mapping. Journal of Management Development. 26(4). doi.101108/02621710710740110. 